\title{
Proceeding
}

Supplementary Issue: Spring Conferences of Sports Science. 15th Convention and Workshop of the International Network of Sport and Health Science, 5-8 June 2019. University of Las Palmas de Gran Canaria, Las Palmas de Gran Canaria, Spain.

\section{Vertical jump test assessment in non-athlete adults: Systematic review}

\author{
INÊS BAPTISTA , JOÃO ABRANTES, TIAGO ATALAIA
}

MovLab/CICANT, Lusophone University of Humanities and Technologies, Portugal

\begin{abstract}
Vertical impulse tests usually designated "jump tests", are regularly carried out in the assessment of physical performance in athletic performers. The present review aims to explore if such tests can be part of the performance evaluation processes in non-athlete performers. To achieve this, a systematic review was conducted according to PRISMA standards. The databases Pubmed, CINAHL Plus, Medline Complete and Google Scholar were accessed. After applying the inclusion and exclusion criteria, seven articles were selected. Overall conclusions indicate that countermovement jump (CMJ) gathered consensus as the preferred method to evaluate physical performance, particularly with the contribution of upper limbs movement and self-selected range of angular knee joint flexion. Other information gathered include test procedures to enhance vertical test results and the gender influence on test results. Keywords: Vertical jump test; Sargent jump; Countermovement jump; Drop jump; Performance assessment; Non-athletes adults.
\end{abstract}

\section{Cite this article as:}

Baptista, I, Abrantes, J. \& Atalaia, T. (2019). Vertical jump test assessment in non-athlete adults: Systematic review. Journal of Human Sport and Exercise, 14(4proc), S543-S557. doi:https://doi.org/10.14198/ihse.2019.14.Proc4.12

\footnotetext{
Corresponding author. Universidade Lusófona de Humanidades e Tecnologias, Campo Grande 376, 1749-024 Lisboa, Portugal. http://orcid.org/0000-0003-2066-1108

E-mail: inesrabaptista@gmail.com

Supplementary Issue: Spring Conferences of Sports Science. 15th Convention and Workshop of the International Network of Sport and Health Science, 5-8 June 2019. University of Las Palmas de Gran Canaria, Las Palmas de Gran Canaria, Spain. JOURNAL OF HUMAN SPORT \& EXERCISE ISSN 1988-5202

(c) Faculty of Education. University of Alicante doi:10.14198/jhse.2019.14.Proc4.12
} 


\section{INTRODUCTION}

Physical performance tests aim to obtain a tangible measure of an individual's performance by the analysis of its components. The outcome of these tests is consider to be a reflex of the body's physical ability to produce the multi-joint movements needed (Hegedus, E. J., McDonough, S., Bleakley, C., Cook, C. E., \& Baxter, G. D., 2015), demonstrating the classic formulation (Bernstein, 1967) that human movement is the result of the control of redundant degrees of freedom. The vertical jump tests have commonly been used in scientific studies as they are considered an effective measurement of the energy expended, and by that offering an indirect measure of the individual's global performance (Klavora, P., 2000). These tests can help the teacher/coach to design the most suitable workout plan that is consistent with the performer's own characteristics, and to identify progress or setbacks in the performer's physical development. This kind of assessment does not require extraordinary technological apparatus and can be easily applied by exercise and health professionals in their normal practice (Hegedus, E. et al., 2015). Its applications may follow several protocols such as the Squat-Jump (SJ), Countermovement Jump (CMJ) and Drop Jump (DJ) tests. SJ consists on a vertical jump performed without previous countermovement, i.e., the initial position already starts from a flexion position of the lower limbs' joints (usually at 90 degrees of knee flection). In the CMJ, the initial position is standing, and the performer need to accomplish a quick countermovement of flexion into extension movement of the lower limbs' joints. By other hand, DJ consist of a jump where the initial position is over a step of different heights and the performer is instructed to fall down the step (drop) into the floor and to jump as soon as it touch the floor (Babillo, J \& Ayestarán, E, 2011). The outcomes of the vertical jump tests give us an idea, not only of the jump height score, but is an outcome that comprises the performer's anatomy, muscular architecture, level of physical activity, motor control and coordination he used to fulfil that score (Markovic, S., Mirkov, D. M., Nedeljkovic, A., \& Jaric, S., 2014; Blache \& Monteil, 2013). As these tests are assumed to be a measure of the total body performance is commonly applied on athletes, regardless the sport modality (Caia, J., Weiss, L. W., Chiu, L. Z., Schilling, B. K., Paquette, M. R., \& Relyea, G. E., 2016). Thus, although the importance of vertical jump tests in the sport environment has been already studied, its application in non-athletes subjects, with different levels of activity, is still unclear.

Considering the basis of scientific knowledge on vertical jump tests (Asmussen \& Bonde-Petersen, 1974; Komi \& Bosco, 1978), this systematic review aims to verify the existence of vertical jump tests application in non-athlete adults.

\section{METHODS}

\section{Experimental approach to the problem}

This systematic review was done according to the Preferred Reporting Items for Systematic Reviews and Meta-Analyses (PRISMA). PRISMA is composed by a set of evidence-based items intended to support researchers reporting and comparing different scientific studies (Moher, D., Liberati, A., Tetzlaff, J., \& Altman, D. G., 2009). In later phases of this review, the "PICO" approach will be used (study population, intervention, control and main results) in order to organize and highlight the main characteristics of each study.

Four databases were accessed from January 2013 to July 2018 (5 years of time bound), aiming to focus on the most current studies about vertical jump tests for performance evaluation. The databases Pubmed, CINAHL Plus, Medline Complete and Google Scholar were accessed with the keywords "vertical jump" and "exercise test". 


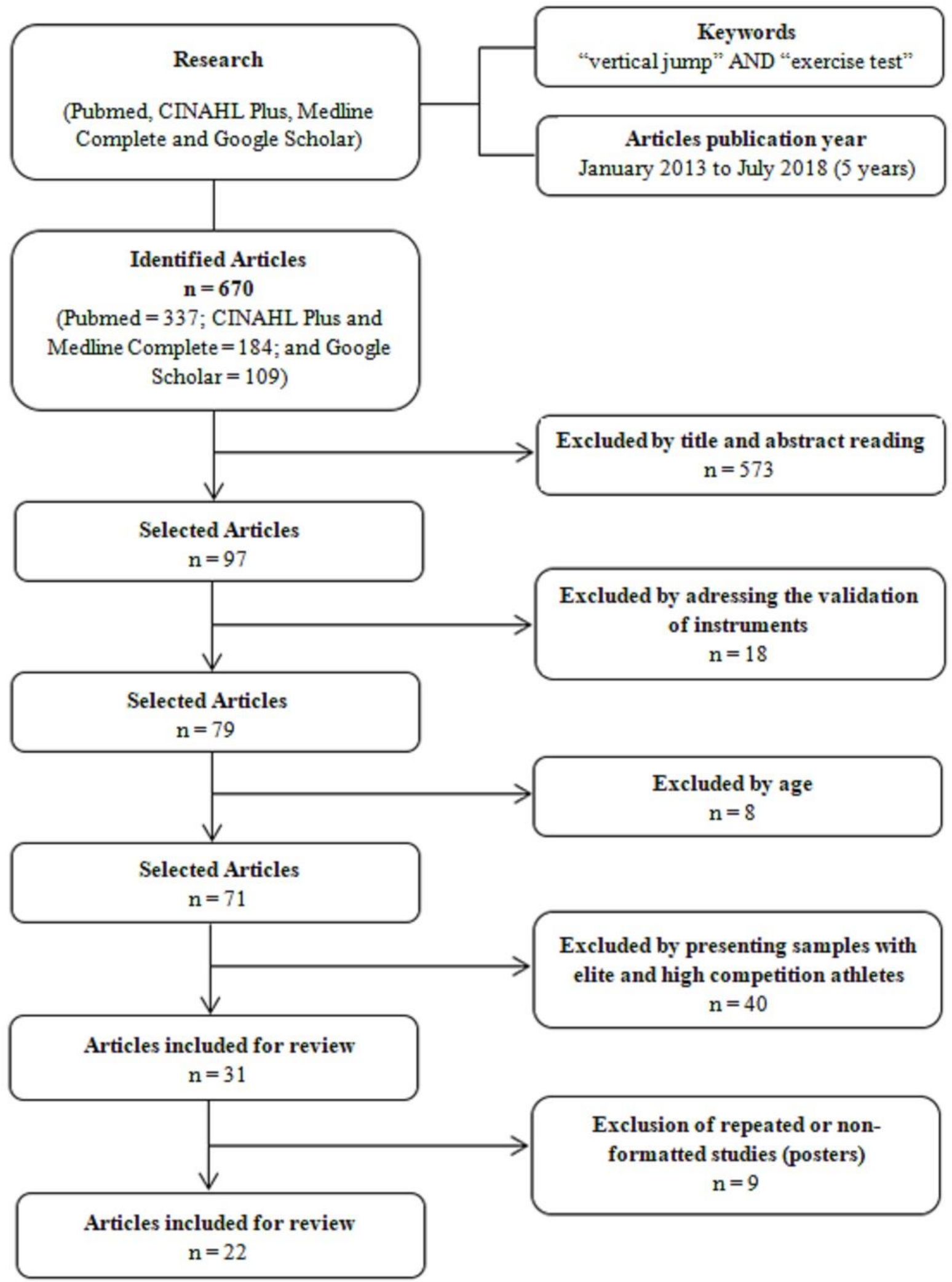

Figure 1. Eligibility flowchart for systematic review articles. 


\section{Subjects}

The articles were selected accordingly to the following inclusion criteria: (1) complete article publications (abstracts or posters are not included), and (2) articles that involve humans in the study samples. The review of the articles included in the selection criteria were then submitted to the review process, consisting of the following procedures: (1) title; (2) abstract reading; (3) integral reading. Exclusion is applied to articles, throughout this process when not meeting the inclusion criteria or the following exclusion criteria: (1) articles addressing the validation of instruments for vertical jump tests (platforms, software, among others); (2) articles including samples with individuals under 18 years old; (3) articles including samples with elite or high competition athletes. In the end, 22 studies were considered for analysis in this review. Figure 1 shows a flow chart of this process.

\section{Procedures}

The analysis of the studies that met the criteria described above was based on the SPIRIT checklist defined by Chan, A. et al. (2013). This is a set of proposed guidelines for scientific trials aimed to support scientific transparency by describing in detail all phases of trials, guaranteeing, this way, the integrity of research protocols (Johansen \& Thomsen, 2016). Considering that two of the studies that met the inclusion criteria referred to systematic reviews and not to scientific trial tests, they should be analysed through the PRISMA checklist, according to Moher, D. et al. (2009). This checklist was developed for reporting systematic reviews and meta-analyses. The summary table is presented below - Table 1 and Table 2 - and the complete tables are presented as supplementary information.

Table 1. Quality analysis of eligible studies - checklist SPIRIT

\begin{tabular}{lc}
\hline Reference & Result \\
\hline Brusco, C. et al. (2018). & $15 / 33$ \\
Caia, J. et al. (2016). & $15 / 33$ \\
Carroll, K. et al. (2018). & $14 / 33$ \\
Cuk, I. et al. (2016). & $11 / 33$ \\
Ercan, S., et al. (2017). & $13 / 33$ \\
Feeney, D. et al. (2016). & $17 / 33$ \\
Ford, K., et al. (2017). & $15 / 33$ \\
Jidovtseff, B., et al. (2014). & $18 / 33$ \\
Kirmizigil, B., Ozcaldiran, B., \&Colakoglu, M. (2014). & $13 / 33$ \\
Mangine, G. et al. (2014). & $17 / 33$ \\
Mayberry, J., Patterson, B., \& Wagner, P. (2018). & $17 / 33$ \\
Ong, J. et al. (2016). & $19 / 33$ \\
Palmer, T. B., Followay, B. N., \& Thompson, B. J. (2017). & $13 / 33$ \\
Pelzer, T., et al. (2018). & $15 / 33$ \\
Pinto, M. et al. (2014). & $19 / 33$ \\
Rouis, M., et al. (2015). & $15 / 33$ \\
Ryan, E. et al. (2014). & $16 / 33$ \\
Singh, H., et al. (2014). & $17 / 33$ \\
Son, C., et al. (2018). & $15 / 33$ \\
Thomas, C., et al. (2015). & $11 / 33$ \\
\hline
\end{tabular}


Table 2. Quality analysis of eligible studies - checklist PRISMA

\begin{tabular}{lc}
\hline Reference & Result \\
\hline Harrison, J. et al. (2017). & $7 / 27$ \\
Vogler, J. et al. (2017). & $7 / 27$ \\
\hline
\end{tabular}

\section{RESULTS}

From the 22 articles selected, were considered those who at least fulfilled $50 \%$ of the respective quality analysis score. In the end, seven articles were included in this systematic review.

Both systematic review articles analysed by PRIMA checklist refer the same source reference (Hegedus, E. et al., 2015), which was considered and analysed accordingly to the same criteria, obtained a score of 20/27. However, this article was not eligible for further analysis because it includes high competition athletes, which was one of the exclusion criteria.

The articles included in this systematic review will be presented in Table 3 and Table 4, that highlights their main characteristics, using the "PICO" method: study population (sample = n), intervention, control and main results/outcomes.

Table 3. Descriptive table of eligible studies

\begin{tabular}{|c|c|c|c|c|}
\hline Reference & Population & Intervation & Control & Mainresults \\
\hline $\begin{array}{l}\text { Feeney, D. } \\
\text { et al. (2016). }\end{array}$ & $\begin{array}{l}10 \text { men with an } \\
\text { average of } 22 \\
\text { years old. }\end{array}$ & $\begin{array}{l}\text { The individuals } \\
\text { performed maximum } \\
\text { vertical } \\
\text { countermovement } \\
\text { jump (CMJ) with a vest } \\
\text { that allowed the } \\
\text { placement of loads } \\
\text { varying from } 0 \% \text { to } 40 \% \\
\text { of body mass. }\end{array}$ & $\begin{array}{l}\text { To analyse the } \\
\text { force-velocity } \\
\text { relationship of } \\
\text { leg muscles; to } \\
\text { evaluate the } \\
\text { reliabilityof the } \\
\text { results } \\
\text { obtained; to } \\
\text { analysethe } \\
\text { changes } \\
\text { associated } \\
\text { tomuscle } \\
\text { workload and } \\
\text { output power. } \\
\text { The kinematics } \\
\text { and kinetics of } \\
\text { the ground } \\
\text { reaction force } \\
\text { and leg } \\
\text { articulation } \\
\text { were recorded. }\end{array}$ & $\begin{array}{l}\text { Strong and nearly linear } \\
\text { relationship of force- } \\
\text { velocity. Although the } \\
\text { increase in load was } \\
\text { associated with a } \\
\text { decrease in both depth of } \\
\text { countermovement and } \\
\text { absolute power, the } \\
\text { absolute work increased, } \\
\text { as well as the relative } \\
\text { contribution of knee work. } \\
\text { The results suggest that } \\
\text { the vertical jumps with } \\
\text { load can be developed } \\
\text { not onlyto test the } \\
\text { capacities of legs } \\
\text { muscles, but also to } \\
\text { reveal the mechanisms of } \\
\text { adaptation of multi- } \\
\text { articular movements } \\
\text { under different load } \\
\text { conditions. }\end{array}$ \\
\hline
\end{tabular}




\begin{tabular}{|c|c|c|c|c|}
\hline $\begin{array}{l}\text { Jidovtseff, } \\
\text { B., et al. } \\
(2014) \text {. }\end{array}$ & 10 adultmen. & $\begin{array}{l}8 \text { verticaljumps: 1) SJ; } \\
\text { 2) CMJ with minimal } \\
\text { flexion of lower limbs; } \\
\text { 3) CMJ with natural } \\
\text { flexion oflower limbs; } \\
\text { 4) CMJ with sharp } \\
\text { flexion of lower limbs; } \\
\text { 5) CMJ with } 20 \mathrm{Kg} \text {; } 6 \text { ) } \\
\text { drop jump with minimal } \\
\text { flexionof lower limbs; } \\
\text { 7) drop jump with } \\
\text { sharp flexion of lower } \\
\text { limbs; 8) } \\
\text { sixconsecutive vertical } \\
\text { jumps. }\end{array}$ & $\begin{array}{l}\text { Comparison } \\
\text { between } 8 \\
\text { different vertical } \\
\text { jumps in: time, } \\
\text { displacement, } \\
\text { speed, } \\
\text { acceleration, } \\
\text { force, power, } \\
\text { impulse and } \\
\text { stiffness. }\end{array}$ & $\begin{array}{l}\text { All the jumps with sharp } \\
\text { flexion of lower limb } \\
\text { produced heel heights } \\
\text { and higher concentric } \\
\text { velocities when } \\
\text { compared to shallow } \\
\text { jumps. The exercises } \\
\text { relatedto higher power } \\
\text { outputs were the drop } \\
\text { jump with minimum } \\
\text { lower limbs flexion and } \\
\text { the six consecutive } \\
\text { vertical jumps, which } \\
\text { involved short pulse } \\
\text { times and very high } \\
\text { accelerations. The } \\
\text { highest values of muscle } \\
\text { stiffness were not } \\
\text { observed during the } \\
\text { highest vertical jumps. } \\
\text { Thismeansstiffness is } \\
\text { not critical for the jump. }\end{array}$ \\
\hline $\begin{array}{l}\text { Mangine, G. } \\
\text { et al. (2014). }\end{array}$ & $\begin{array}{l}28 \text { adults: } 14 \\
\text { menwith } \\
\text { anaverage of } 24 \\
\text { years old; and } 14 \\
\text { women withan } \\
\text { average of } 22 \\
\text { years old. }\end{array}$ & $\begin{array}{l}\text { Phase 1) all subjects } \\
\text { performed ultrasound } \\
\text { to assess the muscle } \\
\text { architecture. } \\
\text { Measurements of } \\
\text { muscle thickness, } \\
\text { penetration angle, } \\
\text { cross-sectional area, } \\
\text { and echo intensity were } \\
\text { collected from the } \\
\text { rectus femoris and } \\
\text { vastus lateralis of both } \\
\text { legs; } \\
\text { Phase 2) } 1 \text { to } 2 \text { days } \\
\text { after phase } 1 \text { the whole } \\
\text { sample performed } 3 x \\
\text { CMJ; } \\
\text { Phase 3) one week } \\
\text { later the whole sample } \\
\text { performed } 3 x \\
\text { meters sprint. }\end{array}$ & $\begin{array}{l}\text { Analysis of the } \\
\text { relationship } \\
\text { between } \\
\text { vertical jump } \\
\text { power peak and } \\
\text { mean, } \quad 30 \\
\text { meters sprint } \\
\text { speed and } \\
\text { muscle } \\
\text { architecture. }\end{array}$ & $\begin{array}{l}\text { Men present lower echo, } \\
\text { greater muscle size, are } \\
\text { faster and powerful than } \\
\text { woman. Gradual } \\
\text { regression showed that } \\
\text { muscle quality and size } \\
\text { influenced speed and } \\
\text { strength in men. In } \\
\text { woman, asymmetry of } \\
\text { the vastus lateralis } \\
\text { adversely affected } \\
\text { vertical jump power peak } \\
\text { and mean, while echo } \\
\text { asymmetry of vastus } \\
\text { lateralis and rectus } \\
\text { femoris positively } \\
\text { influenced the vertical } \\
\text { jump power mean and } 30 \\
\text { meters sprint, } \\
\text { respectively. } \\
\text { muscular architecture of } \\
\text { the thigh seemed to } \\
\text { influence the jump power } \\
\text { and the run speed, }\end{array}$ \\
\hline
\end{tabular}




\begin{tabular}{|c|c|c|c|c|}
\hline & & & & $\begin{array}{l}\text { although the effect may } \\
\text { vary accordingly to } \\
\text { gender in non-athlete } \\
\text { active adults. A proper } \\
\text { assessment of } \\
\text { ultrasound variables } \\
\text { applied in men and } \\
\text { women before training } \\
\text { may provide a more } \\
\text { specific exercise } \\
\text { prescription. }\end{array}$ \\
\hline $\begin{array}{l}\text { Mayberry, } \\
\text { J., } \\
\text { Patterson, } \\
\text { B., \& } \\
\text { Wagner, P. } \\
\text { (2018). }\end{array}$ & $\begin{array}{l}\text { High school } \\
\text { students ( } \mathrm{n}= \\
\text { 1571), university } \\
\text { students ( } \mathrm{n}= \\
393), \\
\text { professionals (n } \\
=373) .\end{array}$ & $\begin{array}{l}\text { 3x CMJ. } \\
\text { Subsequently the } \\
\text { sample was divided } \\
\text { into } 2 \text { groups: treatment } \\
\text { group (with specific } \\
\text { strength training plan) } \\
\text { or control group (in } \\
\text { which athlete chose his } \\
\text { own exercises). }\end{array}$ & $\begin{array}{l}\text { Comparison } \\
\text { between } 2 \\
\text { sample groups } \\
\text { on CMJ } \\
\text { performance in } \\
\text { the variables: } \\
\text { ground reaction } \\
\text { force, eccentric } \\
\text { force } \\
\text { development } \\
\text { rate, vertical } \\
\text { concentric force } \\
\text { and vertical } \\
\text { concentric } \\
\text { impulse. }\end{array}$ & $\begin{array}{l}\text { This study analyses the } \\
\text { efficacy of prescribed } \\
\text { exercises in } \\
\text { theimprovement of } \\
\text { movement quality during } \\
\text { CMJ. There are } \\
\text { significant differences in } \\
\text { changes ground reaction } \\
\text { forces measured } \\
\text { between both groups. } \\
\text { There were identified } 4 \\
\text { primary muscle groups } \\
\text { that should be } \\
\text { considered in efficient } \\
\text { training plans:the divided } \\
\text { squats increase vertical } \\
\text { concentric impulse and } \\
\text { decrease eccentric force } \\
\text { development rate; } \\
\text { deadlifts increase vertical } \\
\text { concentric force and } \\
\text { decrease vertical } \\
\text { concentric impulse; } \\
\text { alternating squats and } \\
\text { split squats increase } \\
\text { eccentric force } \\
\text { development rate and } \\
\text { decrease vertical } \\
\text { concentric force; and } \\
\text { alternate squats/deadlifts } \\
\text { increase eccentric force } \\
\text { development rate and } \\
\text { vertical concentric force, } \\
\text { and decreasevertical } \\
\text { concentric impulse. }\end{array}$ \\
\hline
\end{tabular}




\begin{tabular}{|c|c|c|c|c|}
\hline $\begin{array}{l}\text { Ong, J. et al. } \\
(2016) .\end{array}$ & $\begin{array}{l}14 \\
\text { menbetween } 25 \\
\text { and } 35 \text { years old. }\end{array}$ & $\begin{array}{l}4 \text { CMJ performed } 3,6 \text {, } \\
9 \quad \text { and } 12 \\
\text { minutesaftereccentric } \\
\text { exercise } \\
\text { performedonlegpress } \\
\text { at } 105 \%, 125 \% \text { e } 1 \mathrm{RM} \\
\text { (in 3 different days). }\end{array}$ & $\begin{array}{l}\text { Comparison of } \\
\text { CMJ } \\
\text { performance } \\
\text { results after } \\
\text { different loads } \\
\text { of eccentric } \\
\text { muscle } \\
\text { stimulus. }\end{array}$ & $\begin{array}{l}\text { The best results were } \\
\text { observed in CMJ at } 3 \\
\text { minutes and } 6 \text { minutes in } \\
\text { legpress with previous } \\
\text { work at } 105 \% \text { and } 125 \% \text {. } \\
\text { Thus, individuals can } \\
\text { apply eccentric work in } \\
\text { heating routines to } \\
\text { increase further } \\
\text { performance. }\end{array}$ \\
\hline $\begin{array}{l}\text { Pinto, M. et } \\
\text { al. (2014). }\end{array}$ & $\begin{array}{l}16 \text { men, } \\
\text { between } 20 \text { and } \\
22 \text { years old. }\end{array}$ & $3 x$ CMJ. & $\begin{array}{l}\text { To compare the } \\
\text { performance } \\
\text { and power of } \\
\text { CMJ with the } \\
\text { previous } \\
\text { execution of a } \\
\text { static stretching } \\
\text { position with } \\
\text { less than } 45 \\
\text { seconds or } \\
\text { more that } 60 \\
\text { seconds, or } \\
\text { compared with } \\
\text { no stretching. }\end{array}$ & $\begin{array}{l}\text { Regarding no stretching, } \\
\text { the } 60 \text { seconds stretching } \\
\text { showed worse results in } \\
\text { CMJ, as well as in power } \\
\text { generated. There were } \\
\text { no differences between } \\
\text { the results obtained after } \\
30 \text { seconds stretching } \\
\text { and } 60 \text { seconds } \\
\text { stretching or no } \\
\text { stretching. It is concluded } \\
\text { that the multi-articular } \\
\text { power task (CMJ) can be } \\
\text { impaired if performed } \\
\text { immediately after a } \\
\text { moderate duration } \\
\text { stretching ( } 60 \text { seconds to } \\
8 \text { minutes), while the } \\
\text { short duration stretching } \\
\text { (30 seconds to } 4 \\
\text { minutes) has an } \\
\text { insignificant influence. }\end{array}$ \\
\hline $\begin{array}{l}\text { Singh, H. et } \\
\text { al. (2014). }\end{array}$ & $\begin{array}{l}\mathrm{n}=60 \\
27 \text { men and } 33 \\
\text { woman } \\
\text { (between } 55 \text { and } \\
75 \text { years old). }\end{array}$ & $\begin{array}{l}\text { The body composition } \\
\text { and the sarcopenia of } \\
\text { each individual were } \\
\text { evaluated. } \\
3 \text { vertical jumps were } \\
\text { performed on a jump } \\
\text { mat to evaluate jump } \\
\text { power (JPow), jump } \\
\text { speed (JVel) and jump } \\
\text { height (JHt). Muscle } \\
\text { strength was measured } \\
\text { by the 1RM test on the } \\
\text { legpress (LP) and right }\end{array}$ & $\begin{array}{l}\text { To analyze the } \\
\text { jump power } \\
\text { (JPow) and } \\
\text { muscular } \\
\text { strength, } \\
\text { comparing them } \\
\text { with the status } \\
\text { of sarcopenia in } \\
\text { older adults. }\end{array}$ & $\begin{array}{l}\text { Sarcopenia was found in } \\
20 \%(12 / 60) \text { of the } \\
\text { participants. Jump power } \\
\text { was significantly lower in } \\
\text { the sarcopenia group } \\
\text { compared tothe normal } \\
\text { group. JPow and Jht } \\
\text { were significantly } \\
\text { positively correlated with } \\
\text { ASM and lean body mass } \\
\text { bone free. Significant } \\
\text { positive correlations were } \\
\text { also reported between }\end{array}$ \\
\hline
\end{tabular}




\begin{tabular}{|l|l|l|l|}
\hline & $\begin{array}{l}\text { and left hip abduction } \\
\text { exercises. }\end{array}$ & $\begin{array}{l}\text { the variables of JPow, } \\
\text { JVel and JHt and muscle } \\
\text { strength (LP and right/left } \\
\text { hip abduction). } \\
\text { Individuals classified as } \\
\text { sarcopenic had } \\
\text { significantly lower input } \\
\text { strength but not muscle } \\
\text { strength compared to } \\
\text { other individuals with } \\
\text { normal amounts of } \\
\text { muscle mass. The jump } \\
\text { test variableswere } \\
\text { positively correlated with } \\
\text { lean tissue and legs } \\
\text { muscles strength. Based } \\
\text { on this study JPow may } \\
\text { be useful for screening } \\
\text { sarcopenia in middle- } \\
\text { aged and elderly adults. }\end{array}$ \\
\hline
\end{tabular}

Table 4. Summary table of the eligible studies interventions and outcomes

\begin{tabular}{|l|c|l|l|l|}
\hline References & Population & $\begin{array}{l}\text { Intervention } \\
\text { (Jump) }\end{array}$ & \multicolumn{1}{|c|}{ Control } & \multicolumn{1}{|c|}{ Comparison } \\
\hline $\begin{array}{l}\text { Feeney, D. et } \\
\text { al. (2016). }\end{array}$ & 10 & $\begin{array}{l}\text { CMJ with arms } \\
\text { impulse and } \\
\text { withload } \\
\text { variations. }\end{array}$ & $\begin{array}{l}\text { Strength-velocity } \\
\text { ratio of the leg } \\
\text { muscles. }\end{array}$ & $\begin{array}{l}\text { Between different levels of load in } \\
\text { CMJ performance. }\end{array}$ \\
\hline $\begin{array}{l}\text { Jidovtseff, B. } \\
\text { et al. (2014). }\end{array}$ & 10 & $\begin{array}{l}8 \text { different } \\
\text { vertical jumps } \\
\text { (SJ, CMJ, DJ, } \\
\text { with } \\
\text { variations). }\end{array}$ & $\begin{array}{l}\text { Time, } \\
\text { displacement, } \\
\text { speed, } \\
\text { acceleration, } \\
\text { strength, impulse } \\
\text { and rigidity. }\end{array}$ & $\begin{array}{l}\text { Between different types of vertical } \\
\text { jump. }\end{array}$ \\
\hline $\begin{array}{l}\text { Mangine, G. } \\
\text { et al. (2014). }\end{array}$ & 28 & $\begin{array}{l}\text { CMJ with arms } \\
\text { impulse. }\end{array}$ & $\begin{array}{l}\text { Relationship } \\
\text { between peak } \\
\text { and mean } \\
\text { vertical jump } \\
\text { power and } \\
\text { muscular and } \\
\text { architecture. }\end{array}$ & $\begin{array}{l}\text { Between male and female } \\
\text { individuals. }\end{array}$ \\
\hline $\begin{array}{l}\text { Mayberry, J., } \\
\text { Patterson, B., } \\
\text { \& Wagner, P. } \\
\text { (2018). }\end{array}$ & 2335 & CMJ & $\begin{array}{l}\text { CMJ } \\
\text { performance in } \\
\text { the variables: } \\
\text { ground reaction }\end{array}$ & $\begin{array}{l}\text { Between the existence or not of an } \\
\text { individual training plan for muscle } \\
\text { strength development. }\end{array}$ \\
\hline
\end{tabular}




\begin{tabular}{|l|l|l|l|l|}
\hline & & & $\begin{array}{l}\text { force, eccentric } \\
\text { force rate } \\
\text { development, } \\
\text { vertical } \\
\text { concentric force } \\
\text { and vertical } \\
\text { concentric } \\
\text { impulse. }\end{array}$ & \\
\hline $\begin{array}{l}\text { Ong, J. et al. } \\
\text { (2016). }\end{array}$ & 14 & $\begin{array}{l}\text { CMJ without } \\
\text { arms impulse. }\end{array}$ & $\begin{array}{l}\text { CMJ } \\
\text { performance } \\
\text { (jumpheight). }\end{array}$ & $\begin{array}{l}\text { Between different stimulus loads } \\
\text { prior to CMJ performance. }\end{array}$ \\
\hline $\begin{array}{l}\text { Pinto, M. et } \\
\text { al. (2014). }\end{array}$ & 16 & $\begin{array}{l}\text { CMJ without } \\
\text { arms impulse. }\end{array}$ & $\begin{array}{l}\text { CMJ } \\
\text { performance } \\
\text { (jumpheight). }\end{array}$ & Betweendifferentstretchingdurations. \\
\hline $\begin{array}{l}\text { Singh, H. et } \\
\text { al. (2014). }\end{array}$ & 60 & $\begin{array}{l}\text { CMJ, with } \\
\text { arms impulse }\end{array}$ & $\begin{array}{l}\text { Jump power and } \\
\text { muscular } \\
\text { strength. }\end{array}$ & Between individuals with different \\
levels of sarcopenia.
\end{tabular}

\section{DISCUSSION}

\section{Intervention}

Based on the gathered evidence, CMJ is the most commonly used test for the evaluation of vertical jump, with or without arm impulse, in non-athletes. This matches existing evidence that compares the results between CMJ and other protocols such as the SJ or DJ (Bobbert \& Casius, 2005). Accordingly to the same authors this can be justified by a difference in active state during the propulsion phase of both jump protocols: in CMJ the active state is developed during the preparatory countermovement, where as in SJ it inevitably developed during the propulsion phase. When released the tension developed in CMJ preparatory countermovement, it increases the contractile capacity of the muscle at the propulsion phase of vertical impulsion, producing more energy and, consequently, obtaining better results - cycle stretching-shortening.

Four out of the seven reviewed articles added on their intervention protocols the arms for impulse. In two studies, the hands were positioned on the waist and in one other the used protocol was unclear. The permission to use the swing propulsion movement of the arms for vertical jump execution, adopted by most of the authors, sustain the idea that this impulse can significantly improve the performance in the vertical test and related outcome result (Harrison, A., \& Moroney, A., 2007; Akl, A., 2013).

Regarding the allowed lower limbs' joint range of motion in the vertical jump performance, the jumps with an accentuated lower limbs range of flexion have produced higher heights scores and higher concentric velocities compared to the jump performed with less flexion on the three main joints, ankle, knee and hip (Jidovtseff, B., Quievre, J., Nigel, H., \& Cronin, J.,2014). Just one of the included studies, the range of flexion was imposed prior to analysis, as the remaining studies did not have an imposed range on their samples. Moreover, in a study of Domire \& Challis (2007) the authors found that there were no significant differences between the jumps performed with imposed initial deep squatter position or self-selected flexion. Concluding, the performance outcomes were more related with individual coordination than to a condition of imposed squatting position or pre-selected lower limbs' flection. According to the same authors, the vertical jumps 
performed with grater flexion at the initial position is not common or consensual, since it seems to require more effort and increased tension in tendons and joints involved than those were a free initial position is allowed. These results were also supported by other study of Gheller, R. G., Dal Pupo, J., Ache-Dias, J., Detanico, D., Padulo, J., \& dos Santos, S. G. (2015), in which better performances were observed in jumps executed freely regarding the lower limb amount of flection.

Accordingly, to the results of this review, it seems that vertical jumps performance in non-athletes is influenced by gender and age. It was observed that the masculine gender present measures of muscular size and thickness significantly greater as compared to those of the feminine gender, which can be responsible for higher values of contractile velocity and muscular power (Mangine, G. et al., 2014). The same conclusions were obtained by Quatman, C. E., Ford, K. R., Myer, G. D., \& Hewett, T. E. (2006). These authors also observed that this gender difference exists since early age, as in the normal growing process, men gradually and significantly reduce their reaction time and simultaneously increase their force and muscular power.

The study of Singh, H., et al., (2014) demonstrates that lower values in power and impulse register in jump tasks are present in older performers. These results also support the former concept from Bosco \& Komi, (1980) were the best results - peak performance - in the variables mean strength, centre of gravity height, impulse and power, were seen in both genders between the ages of 20 and 30 years old. From the age of 30 and more, the performance tends to decrease with the maturation and aging processes that affect the muscle elastic behaviour and its reflex power (Palmer, T., Followay, B., Thompson, B., 2017).

\section{Muscle activation}

The relationship between vertical jump performance and different levels of individual muscular activation in non-athletes, either by increasing external loads, by previous muscle stimulation work, or previous muscle stretching work, was the aim of five studies.

The human body behaviour in the performance of the vertical jump is adapted to the increment of external load (Feeney, D., Stanhope, S. J., Kaminski, T. W., Machi, A., \& Jaric, S., 2016). A deeper depth of the countermovement and an increased muscular power has been observed as an adaptation to load increment. Performing vertical jumps with $5 \%$ of external load can increase the jump performance after removing the load (Hoffman, A., Halteman, T., Hamzabegovic, S., Wallace, C., Paulson, S., \& Sanders, J., 2018). It was also seen that different strength exercises focusing the lower limbs (squats and deadlifts) contribute to increased efficiency of the vertical jump execution, through development of muscular groups responsible for concentric and eccentric energy production (Mayberry, J. K., Patterson, B., \& Wagner, P., 2018). Better performance results were observed after previous leg press exercise work at $105 \%$ and $125 \%$ of $1-\mathrm{RM}$ (one repetition maximum), meaning that the usage of lower limb strength exercises routines in the warm-up will contribute to superior performance results (Ong, J. H., Lim, J., Chong, E., \& Tan, F.,2016).

Regarding the develop of stretching muscles routines as a way to enhance the vertical jump outcomes, Pinto, M. D., Wilhelm, E. N., Tricoli, V., Pinto, R. S., \& Blazevich, A. J. (2014), concluded that CMJ performance may be decreased after static stretching from 60 seconds to 8 minutes, and there is no influence on jump performance if static stretching decreases its duration from 30 seconds to 4 minutes. This evidence is supported by Brusco, C. M., Pompermayer, M. G., Esnaola, B. W., Lima, C. S., \& Pinto, R. S. (2018), with a study that demonstrated relation of lower limb power reduction on $\mathrm{CMJ}$ after a passive static stretching for 30 seconds with consequent reduction of vertical jump outcome scores. A static stretching of 20 seconds, however, seems to contribute to significantly better results in CMJ outcome scores (Ercan, S., Başkurt, Z., 
Başkurt, F., \& Parpucu, T. İ., 2017). Accordingly to Kirmizigil, B., Ozcaldiran, B., \& Colakoglu, M.,(2014), the dynamic and proprioceptive stretches seems to lead to an improvement in CMJ outcome scores, in different levels of flexibility, as compared with those register after static stretching protocols. However, when these stretching methods were combined with static stretching for 30 seconds, there was a decrease in CMJ performance.

\section{CONCLUSIONS}

Most of vertical jump tests studies samples are composed by athletes, although and event less prevalent, there are also some studies of non-athletes. It is even less observable the existence of studies that apply vertical jump tests in non-athletes in adults between 30 and 50 years old, prevailing young adults samples with 20 years old average.

Accordingly to the results of this review the vertical impulse test protocol most used in studies with nonathletes is the CMJ.

\section{ACKNOWLDGMENTS}

We thank Universidade Lusófona de Humanidades e Tecnologias and MovLab - Laboratory of Interactions and Interfaces for support. The results of the present study do not constitute endorsement of the product by the authors or the NSCA.

\section{REFERENCES}

Akl, A. (2013). The role of biomechanical parameters and muscle activity during eccentric and concentric contractions in vertical jump performance. Journal of Physical Education and Sport, 13(3), 430.

Asmussen, E., \& Bonde-Petersen, F. (1974). Storage of elastic energy in skeletal muscles in man. ActaPhysiologica, 91(3), 385-392. https://doi.org/10.1111/j.1748-1716.1974.tb05693.x

Badillo, J. \& Ayestarán, E. (2001). Fundamentos do treinamento de força: Aplicação ao alto rendimento desportivo. Artmed, editor. Porto Alegre: $2^{\text {a }}$.

Bernstein, N. A. (1967). The coordination and regulation of movement. London.

Blache, Y., \& Monteil, K. (2013). Effect of arm swing on effective energy during vertical jumping: experimental and simulation study. Scandinavian journal of medicine \& science in sports, 23(2), 121 129. https://doi.org/10.1111/sms.12042

Bobbert, M., \& Casius, L. (2005). Is the effect of a countermovement on jump height due to active state development? Med. Sci. Sports Exerc, Vol. 37, No. 3, pp. 440- 446. https://doi.org/10.1249/01.mss.0000155389.34538.97

Bosco, C. \& Komi, P. (1980). Influence of aging on the mechanical behavior of leg extensor muscles. European journal of applied physiology and occupational physiology, 45(2-3), 209-219. https://doi.org/10.1007/bf00421329

Brusco, C. M., Pompermayer, M. G., Esnaola, B. W., Lima, C. S., \& Pinto, R. S. (2018). Short duration static stretching preceded by cycling warm-up reduces vertical jump performance in healthy males. Sport Sciences for Health, 14(1), 77-82. https://doi.org/10.1007/s11332-017-0404-3

Carroll, K. M., Bernards, J. R., Bazyler, C. D., Taber, C. B., Stuart, C. A., DeWeese, B. H., \& Stone, M. H. (2018). Divergent Performance Outcomes Following Resistance Training Using Repetition Maximums or Relative Intensity. International journal of sports physiology and performance, 1-28. https://doi.org/10.1123/ijspp.2018-0045 
Caia, J., Weiss, L. W., Chiu, L. Z., Schilling, B. K., Paquette, M. R., \& Relyea, G. E. (2016). Do lowerbody dimensions and body composition explain vertical jump ability?. Journal of strength and conditioning research, 30 (11), 3073-3083. https://doi.org/10.1519/isc.0000000000001406

Chan, A. W., Tetzlaff, J. M., Altman, D. G., Laupacis, A., Gøtzsche, P. C., Krleža-Jerić, K., \& Doré, C. J. (2013). SPIRIT 2013 statement: defining standard protocol items for clinical trials. Annals of internal medicine, 158(3), 200-207. https://doi.org/10.7326/0003-4819-158-3-201302050-00583

Cuk, I., Mirkov, D., Nedeljkovic, A., Kukolj, M., Ugarkovic, D., \& Jaric, S. (2016). Force-velocity property of leg muscles in individuals of different level of physical fitness. Sports biomechanics, 15(2), 207 219. https://doi.org/10.1080/14763141.2016.1159724

Domire, Z.\& Challis, J. (2007). The influence of squat depth on maximal vertical jump performance. J Sports Sci, 25(2), 193-200. https://doi.org/10.1080/02640410600630647

Ercan, S., Başkurt, Z., Başkurt, F., \& Parpucu, T. İ. (2017). The Acute Effect of Static and Dynamic Stretching on Horizontal and Vertical Jump.International Journal of Sport Studies. Vol., 7 (3), 167173.

Feeney, D., Stanhope, S. J., Kaminski, T. W., Machi, A., \& Jaric, S. (2016). Loaded vertical jumping: force-velocity relationship, work, and power. Journal of applied biomechanics, 32(2), 120-127. https://doi.org/10.1123/jab.2015-0136

Ford, K. R., Nguyen, A. D., Hegedus, E. J., \& Taylor, J. B. (2017). Vertical Jump Biomechanics Altered With Virtual Overhead Goal. Journal of applied biomechanics, 33(2), 153-159. https://doi.org/10.1123/jab.2016-0179

Gheller, R. G., Dal Pupo, J., Ache-Dias, J., Detanico, D., Padulo, J., \& dos Santos, S. G. (2015). Effect of different knee starting angles on intersegmental coordination and performance in vertical jumps. Human movement science, 42, 71-80. https://doi.org/10.1016/j.humov.2015.04.010

Harrison, A. \& Moroney, A. (2007). Arm augmentation of vertical jump performance in young girls and adult females. ISBS-Conference Proceedings Archive, Vol. 1, No. 1.

Harrison, J. J., Yorgey, M. K., Csiernik, A. J., Vogler, J. H., \& Games, K. E. (2017). Clinician-Friendly Physical Performance Tests for the Knee. Journal of athletic training, 52(11), 1068-1069. https://doi.org/10.4085/1062-6050-52.11.19

Hegedus, E. J., McDonough, S., Bleakley, C., Cook, C. E., \& Baxter, G. D. (2015). Clinician-friendly lower extremity physical performance measures in athletes: a systematic review of measurement properties and correlation with injury, part 1. The tests for knee function including the hop tests. $\mathrm{Br} \mathrm{J}$ Sports Med, 49(10), 642-648. https://doi.org/10.1136/bjsports-2014-094094

Hoffman, A., Halteman, T., Hamzabegovic, S., Wallace, C., Paulson, S., \& Sanders, J. (2018). The Acute Effects of Loaded Jump on Vertical Jump Performance and Perception. International Journal of Exercise Science: Conference Proceedings, Vol. 9, No. 6, p. 54.

Jidovtseff, B., Quievre, J., Nigel, H., \& Cronin, J. (2014). Influence of jumping strategy on kinetic and kinematic variables. Journal of sports medicine and physical fitness, 54, 129-138.

Johansen, M., \& Thomsen, S. (2016). Guidelines for reporting medical research: a critical appraisal. International scholarly research notices. https://doi.org/10.1155/2016/1346026

Klavora, P. (2000). Vertical-jump Tests. Strength and Conditioning Journal, 22(5), 70.

Kirmizigil, B., Ozcaldiran, B., \& Colakoglu, M. (2014). Effects of three different stretching techniques on vertical jumping performance. The Journal of Strength \& Conditioning Research, 28(5), 1263-1271. https://doi.org/10.1519/jsc.0000000000000268

Komi, P.\& Bosco, C. (1978). Muscles by men and women. Med Sci Sport, 10, 261-265.

Mangine, G. T., Fukuda, D. H., LaMonica, M. B., Gonzalez, A. M., Wells, A. J., Townsend, J. R., \& Hoffman, J. R. (2014). Influence of gender and muscle architecture asymmetry on jump and sprint performance. Journal of sports science \& medicine, 13(4), 904. 
Markovic, S., Mirkov, D. M., Nedeljkovic, A., \& Jaric, S. (2014). Body size and countermovement depth confound relationship between muscle power output and jumping performance. Human movement science, 33, 203-210. https://doi.org/10.1016/..humov.2013.11.004

Mayberry, J., Patterson, B., \& Wagner, P. (2018). Improving vertical jump profiles through prescribed movement plans. The Journal of Strength \& Conditioning Research, 32(6), 1619-1626. https://doi.org/10.1519/jsc.0000000000002248

Moher, D., Liberati, A., Tetzlaff, J., \& Altman, D. G. (2009). Preferred reporting items for systematic reviews and meta-analyses: the PRISMA statement. Annals of internal medicine, 151(4), 264-269. https://doi.org/10.7326/0003-4819-151-4-200908180-00135

Ong, J. H., Lim, J., Chong, E., \& Tan, F. (2016). The Effects of Eccentric Conditioning Stimuli on Subsequent Counter-Movement Jump Performance. The Journal of Strength \& Conditioning Research, 30(3), 747-754. https://doi.org/10.1519/jsc.0000000000001154

Palmer, T., Followay, B., \& Thompson, B. J. (2017). Age-related effects on maximal and rapid hamstrings/quadriceps strength capacities and vertical jump power in young and older females. Aging clinical and experimental research,29(6), 1231-1239. https://doi.org/10.1007/s40520-0170734-7

Pelzer, T., Ullrich, B., Endler, S., Rasche, C., \& Pfeiffer, M. (2018). A biomechanical comparison of countermovement performance after short-term traditional and daily-undulated loaded vertical jump $\begin{array}{llll}\text { training. Journal of sports } & \text { sciences, }\end{array}$ https://doi.org/10.1080/02640414.2017.1422627

Pinto, M. D., Wilhelm, E. N., Tricoli, V., Pinto, R. S., \& Blazevich, A. J. (2014). Differential effects of 30 vs. 60 -second static muscle stretching on vertical jump performance. The Journal of Strength \& Conditioning Research, 28(12), 3440-3446. https://doi.org/10.1519/jsc.0000000000000569

Quatman, C. E., Ford, K. R., Myer, G. D., \& Hewett, T. E. (2006). Maturation leads to gender differences in landing force and vertical jump performance: a longitudinal study. The American journal of sports medicine, 34(5), 806-813. https://doi.org/10.1177/0363546505281916

Rouis, M., Attiogbé, E., Vandewalle, H., Jaafar, H., Noakes, T. D., \& Driss, T. (2015). Relationship between vertical jump and maximal power output of legs and arms: effects of ethnicity and sport. Scandinavian journal of medicine \& science in sports, 25(2), e197-e207. https://doi.org/10.1111/sms.12284

Ryan, E. D., Everett, K. L., Smith, D. B., Pollner, C., Thompson, B. J., Sobolewski, E. J., \& Fiddler, R. E. (2014). Acute effects of different volumes of dynamic stretching on vertical jump performance, flexibility and muscular endurance. Clinical physiology and functional imaging, 34(6), 485-492. https://doi.org/10.1111/cpf.12122

Singh, H., Kim, D., Kim, E., Bemben, M. G., Anderson, M., Seo, D. I., \& Bemben, D. A. (2014). Jump test performance and sarcopenia status in men and women, 55 to 75 years of age. Journal of Geriatric Physical Therapy, 37(2), 76-82. https://doi.org/10.1519/jpt.0b013e3182a51b11

Son, C., Stewart, A., Ward, J., \& Farrar, K. (2018). Lower Body Strength-Training Versus Proprioceptive Exercises on Vertical Jump Capacity: A Feasibility Study. Journal of chiropractic medicine, 17(1), 715. https://doi.org/10.1016/j.jcm.2017.10.007

Thomas, C., Jones, P. A., Rothwell, J., Chiang, C. Y., \& Comfort, P. (2015). An investigation into the relationship between maximum isometric strength and vertical jump performance. The Journal of $\begin{array}{llll}\text { Strength \& Conditioning 2176-2185. } & \text { Research, }\end{array}$ https://doi.org/10.1519/jsc.0000000000000866

Vogler, J. H., Csiernik, A. J., Yorgey, M. K., Harrison, J. J., \& Games, K. E. (2017). Clinician-Friendly Physical Performance Tests for the Hip, Ankle, and Foot. Journal of athletic training, 52(9), 861-862. https://doi.org/10.4085/1062-6050-52.7.07 
